\title{
欧米での産業ロボットの動 向*
}

\author{
A Glimpse of the Industrial Robots in the U.S. and \\ the Western Europe* \\ by Chihiro Kojima**
}

小島 千 尋**

アメリカの GM 社及びイタリーの FIAT 社の組立 工場ならびにロボットメーカーの Unimation 社, ASEA Roboties（U.S.A.）の工場を1984年 5 月飞見学する 機会があった。

短い時間でのグループでの視祭であり，最新のロボッ 卜技術というむのには接することが出来なかった。しか し，ロボットによって，生産現場が，徐々にではあるが 確実に変わりつつあることを感じることが出来た．

こ扎迄の私の知り得た情報では, 西ヨーロッパやアメ リカでは，ロボットの導入が失業につながるものとして， 労働組合の反対が強いということであった。したがって， イタリーの FIAT 社の Mira Fiora 組立工場の見学 も，その様な先入観からあまり期待していなかった、1 タリーでは共産党の力が強く，特に FIAT の工場群の ある北イタリーでは支持率が高いからである。しかしな がら，実際には，ロボットの導入が非常に進んでおり， 工場幹部は，自分のところの技術レベルに非常に自信を 持っていて，乙れからあ品質向上及び省力化のために， メカトロ化を進めようとしていた。

また，労働組合との摩擦は，以前にはあったが，今は 全く問題はないと胸をはっていた。

工場の中は，天井が高く広々として，女性作業員むか なり見うけられ，どてとなくゆっくりしたテンポで作業 を行っており，また，あちてちの片隅には，雑然と部品 が積んであるなど，いかにもイタリーらしい雾囲気であ った。しかし，プレスと125台あのハンドリングロボッ 卜，溶接ロボットが非常にシステマティックに配置され て，能率よく動いており，塗装ラインにも12台のロボッ

*原稿受付 昭和59年 9 月14日

日揮(株) JGC Corporation
トが設置されていた。さらにドアヒンジの取付けに視 覚センター付組立口ボットを導入するなどの計画も進め られていた。

又アメリカでは, Ohio 州にある GM 社の Lordstown 工場を訪問した。ここは，従業員約 8,000 人で年間 22 万 台の大型乗用車を生産しており，前述の FIAT の工場 （従業員 10,000 人，小型乗用車 1,450 台/日）とほぼ同 じような規模であるが，ロボットはスポット溶接に28台 (26台稼動，2台オーバーホール) が使用されているだ けで，表面的には FIAT ほどロボット化が進んでいな い.

工場見学後，昼食をとりつつ懇談したが，工場幹部だ けでなく，U.A.W. (全米自動車労組) の職場代表も同 席した。このあたりに会社側のブルーカラーに対するア メリカらしくない気つかかというあのか感じられた。

この席上で，ロボット導入は品質向上が主目的で，ま た悪条件の作業からの人間の解放を目的としており，口 ボット導入にも拘らず实際の労㗢力は增加しているとい う事を工場幹部は強調していた。また，組合代表は U。 A.W.は産業別組織であり，職種別の組織ではないの で, 雇侑が確保されるならば認めていくと説明し，会社 側となかなか息のあったところを見せていた．

欧米の労働者は，溶接工なら溶接工，機械工なら機械 エとそれぞれ自分の職種に対して強烈なプロ意識を持っ ていて，自分の持分を他の職種の労働者が侵す事は絶対 に認ぬないが，自分も他の職種には手を出さないと言わ れている。しかし，口ボットの様な機械之電気，電子が 一体となった装置の保守, 保全, 特に緊急の修理などは, この様な従来の業務のやり方での対応は, 難しいと思わ れる. そのために FIAT では, 保全担当の機械工には 
電気の，電気工には機械の教育を行って，問題を解決し たいと言っていた，一方，GM はてれをさらに進めて， 保全工の中にゥィーマー WEMR (Welding Equipment, Maintenance and Repair) という複合的機 能を持った新しい職種を作り 60人の WEMR で溶接 ロボットなどのメカトロ設備の保守，保全を行っている。 さらに保全エのエレクトロニックスのレベルアップを図 るため,コンピューターを利用した教育システムを開発 し，いつでも端末を利用して独習ができるようにすると 共に，業務に関連した技術習得には，賃金を支払うとい つた方策をとるなど，従来のいわゆる欧米での労働慣行 の改革をすすぬている。

$\mathrm{GM}$ 社では, 1980年には 425 台のロボットが, 現在 1984年には 2,400 台之增加したが， 5 年後には，14,000 台を予定しているという，見在迄は試行段階であり，乙 れから本格的な導入を迎えると言えるが，周到な準備の もとに進めているとはいえ，乙の様な大量のロボットの 導入は，労使関係化さらに大きなインパクトを与えると 予想される。

FIAT，GM などの自動車メーカーで共通しているの は、口ボットの自家生産の動きである. FIAT では今迄， Unimation 社などロボットメーカーから単体の溶接ロボ ットを購入していたが, COMAU 社製に取り換えつつあ る. COMAU 社は, FIAT 95\% 出資の会社で, FIAT 社の自動車製造設備の主要部分の多くは同社製であり，

メカトロ技術開発には，ユーザーである FIAT と一体 となって進めているようである。

ロボットのメンテナンスに対して，前述したとおり， GM は相当に力を入れているのであるが，GM より， はるかに多いロボットを使用している FIAT の体制が 何となく弱いように感じられた。しかし，COMAU 社 が控えているので，その体制で十分なのかししれない。

ドイッの VOLKS WAGEN 社や,フランスのRENAULT 社でも，ロボットの導入を進めているが，いずれ 屯自社 (VW)，または自社柔列メ一カー(RENAULT) で開発するのが基本のようである。

アメリカは， ヨーロッパとは異なり，ロボット専業メ 一カーから睡入していたのだが，GM は1983年にフォ ナックの合弁で GMF を設立し，生産を開始している.

大量のロボットを使用するとなると，個々のロボット の性能と共に，口ボットとロボット，ロボットと他の装 置との関係が重要となってくる，乙の様なトータルシス テムの設計という事になると、ユーザー側からのアプロ 一チの方が容易であり, 自動車工業の上うに, 口ボット を製造するに必要な機械，制御関係の基礎技術を既に持
っている所では，自社生産が主体となっていくのは当然 といえよう。

ロボットの最大のユーザーであった自動車工業におけ るてのような, ハードオリエンテッドから，システムオ リエンテッドへの移行はロボット専業メーカーに大きな 影響老与えつつある.

ロボット専業メーカとして今回は, 㦃業用ロボットの 草分けで、ベンチャービジネスしてスタートしてロボ ッ卜業界と共に急成長した Unimation 社と，一方は 世界的な重電メーカーASEA 社をバックに米国に進出 した ASEA Robotics (U.S.A.) の 2 社を見学した が，ロボットの今後の展開を考える上で，乙の両社の新 状況への対応の仕方はまことに興味深いものがあった。

Unimation 社は, New York 近郊の Danbury に 本社と工場があり，約 400 人 の还業員が働らいている. （この他海外飞 300 人，西独と英国江場がある。）あまり の急成長のために本格的な工場の建設が間に合わず，8 工場にも分散していたが，ようやく新工場の第一期工事 が完成し，4工場に整理されたところである。しかし， 皮肉な事に売上は，6，800万ドル（1981年）を頂点に自 動車産業からの溶接ロボットなどの受注の減少之侕格の 低下により，不振を続けており，トップの座も新興の GMF に奪われてしまうという苦境に㧍ちいり，Westinghouse の傘下に入る事となった。

Unimation 社では,乙执ら目標としている分野とし て，自動車産業向けでは組立ロボッ卜，一般産業部門で は，梱包パレタイジング関係，医薬品工業の無菌作業な ぞ，また将来の有望分野として看護口ボットなどが而 白いといっていた。

てれらから感じられることは，同社が従来から得意と してきたスタンドアロン型で，しかも生産ロットが大き い分野向けの口ボットを狙っているようである。

Unimation 社では, ロボットの Remanufacturing にもまた力を注いでいる。てれは，50,000 時間以上稼動 した古いロボットをオーバーホールし，部分品や制御系 を交換して，新品同様の口ボットに再生させる事であり， 性能的には新しいロボットと全く変らないが，再生費用 としては新品の 6 割ですむとの説明であった. Unimation 社で生産したロボットの累計も, 8,000 台以上に達 したとの事で, 更新需要も相当なものがあるとは思うが, 50,000 時間という事は，お〉よそ10年前の製品であり， 部分的な更新をすれば，今でも十分に通用するというの は，Unimation の基本設計の優秀さを示すむのといえ よう。しかし、ロボットの販売価格は，競争の激化を反 
映して急速に低下したため，ほとんど赤字に転落してい るというような現在の状沉では，乙のような Remanufacturing は，利益を確保する一つの方法といえよう。

ASEA Robotics (U.S.A.) は，乙れとは全く対照 的であった. ASEA のロボットは, ヨーロッパでのシ ェアてそトップであるが,アメリカでのシェアは低く， 1982年 8 月に Milwaukee 郊外 New Berlin K工場を 建設し，本格的にアメリカでの地位を獲得しようとする 所である.1983年のロボット生産台数は 181 台であった が，1984年 320 台，1985年 500 台と漸增していく事を予 定しているが，ほぼ計画よ゙おりに進んでいるという。し かし, 現状の生産台数犬゙けからいうと, Unimationの 数分の一という規模に較べて, 工場従業員は 200 人と多 く，そのうち60\%はエンジニアであり，直接生産ライン に従事している作業者の数は少ない。ロボットの研究開 発および設計の主体は，スエーデンの ASEA 本社で行 い，本社から送られてきた図面に基いて工場で生産をし ているのだが、ワークセルのデザイン（外周設計）は， それぞれのユーザーにより異なるので，工場のエンジニ アが行い，本社のデータバンクに登録するという方法を とっている，全て受注生産であるが，そのうち約80\%は 汎用タイプであり，残りは注文主の指定によるものであ る.製品の70\%は現在であ自動車工業向けだが，1985 年には，視覚を持った浴接ロボットとか，ある種の組立 ロボットなど機能を持った機種の出荷を予定しており, 自動車向けの割合が高くなっていく見通しを持っている. ロボットの今後の方向としては，基本的にはロボット は生産システムの中の一つの自動化の手段であり， CAD /CAM などと組合せたりフトが，極めて重要と考えて 抢り，ロボット単体の製造だけでなく，FMS 関連分野 への進出と，そのために自動化に強い会社の吸収なども 検剖しているとの説明があった。

実際に，ての New Berlinでも ASEA のロボット 部門と共に, ASEA $の$ Industrial Systems, Process Automation，挍よび Power System の各部門が同 じ建物の中で業務を行っており，ASEA の総合的な技 術蓄積をロボットのソフト部門に活用していくという積 極的な姿勢が感じられた。

少し本題からはずれるが，アメリカで現地生産を開始 するにあたって，ASEA でさえも，いろいろ予期せぬ 困難があったようである.

ロボットの部品をアメリカのメーカーに製作させよう としたが、アメリカのエンジニアが馴れている図面では
なく，スエーデン規格の図面そのままでは，十分理解で きない点とか, 表示法として不完全な部分があったりし た. 寸法にしても，アメリカはメートル法でなく，測定 方法が異なるなどのためすあり，公差の上限か下限にひ どく片寄ってしまった事ああった。 また，工程について の考え方む，スエーデンとは大幅に異なっていたとの事 である. 靦在では，これらの問題を完全に克服して， ASEA 製品としての互換性と信頼性が，完全に確保さ れている事を強調していた。

ヨーロッパ文化を共有しているスエーデンとアメリカ の間でさえ，乙のようなギャップがあり，まして我国が 海外で機材を調達する場合に，問題があるのが当然とい えよう.

てのように, ASEA と Unimationは, 生まれる育 ちも全く翼なるが，2つの重要な点に打いて共通してい た.一つは，従業員の教育訓練モーラルアップを極めて 重視していることであり，特に，Unimation 社では， 活発に QC 活動を進める一万では, 從業員の誕生日の お祝いをするとか，Open House といって，每年作業 員の家族を工場に招いて，親や夫，妻が働いている所を 見せるなどの行事を行なっている。

第 2 に、口ボットの信頼性を確保するため, 工場内の 整理整頓，部品の受入検查および管理に力を注ぎ，生産 された全てのロボットは, 苛酷な条件（設計荷重下での 連続長時間運転)て性能を確認してから出荷している。 従業員のモーラルアップあ, 手作業に依頼する部分の極 めて多いロボットの組立では, 信頼性执よび生産性をあ げていくための方法と考える事もできるが，いずれにし ろ, 表面的にはいわゆる日本的経営の類似が指適できよ う.このような現象は，口ボット製造という特殊な分野 での中小規模の企業の動きだけかむしれない。しかし， 我々が Unimation 社を訪れた日は，ちょうど, Westinghouse の会長の初視察の日でああり，その日の午後 は、ブルーカラーを含む全従業員が会長との集会に出席 するなど，我国ですらまれと思われる事が行なわれてお り,アメリカの大企業の経営の姿勢も变化しつつあるの ではなかうか。

以上，限られた範囲での視察であり，盲人が象の一部 を触って議論しているような報告であるが，変化しつつ ある欧米の産業ロボットの状況の参考にして頂ければ幸 いである. 